\title{
Risk Assessment of Rainwater Overflow from Lake Warouwaye in the Case of a Ten-Year Rainfall in Yeumbeul North, Senegal
}

\author{
Benewende Anthelme Victor Sondo ${ }^{1,2}$, Saïdou Ndao ${ }^{1,2}$, Papa Babacar Diop Thioune ${ }^{1,3}$, \\ El Hadji Bamba Diaw ${ }^{*}$ \\ ${ }^{1}$ Laboratory of Sciences and Technology of Water and Environment (LaSTEE), Polytechnic School of Thiès, Thiès, Senegal \\ ${ }^{2}$ Faculty of Science and Technology, University of Thiès, Thiès, Senegal \\ ${ }^{3}$ Higher Institute of Agricultural and Rural Training (ISFAR), University of Thies, Bambey, Senegal \\ Email: *elhbdiaw@ept.sn
}

How to cite this paper: Sondo, B.A.V., Ndao, S., Thioune, P.B.D. and Diaw, E.H.B. (2021) Risk Assessment of Rainwater Overflow from Lake Warouwaye in the Case of a Ten-Year Rainfall in Yeumbeul North, Senegal. Open Journal of Modern Hydrology, 11, 39-53.

https://doi.org/10.4236/ojmh.2021.113003

Received: May 31, 2021

Accepted: June 26, 2021

Published: June 29, 2021

Copyright $\odot 2021$ by author(s) and Scientific Research Publishing Inc. This work is licensed under the Creative Commons Attribution International License (CC BY 4.0).

http://creativecommons.org/licenses/by/4.0/

(c) (i) Open Access

\begin{abstract}
This study is a part of a global approach in which, the main purpose is to understand the reasons behind the upsurge of flood events in the peri-urban area of the city of Dakar. Hydrological and hydraulics simulations were carried out to assess the risks of overflowing of the Lake Warouwaye after a so-called exceptional rain. Data were collected through field surveys, as well as site observations of dwellings before and after rain episodes. The simulations were performed using EPA's Storm Water Management Model (SWMM) software with input data obtained from sub-software and supervisory applications such as Google Earth, Excel, and Global Mapper. The simulation results show factors of natural and anthropogenic origin may contribute to dysfunction hydrological elements such as the watershed capacity to drain and store water. In light of the results of this study, institutional governance efforts are to be made and to be sustained in order to reverse the tendency to occupy rainwater natural flow channels. It will also be necessary to involve the first actors who are the potential victims of flooding caused by the recurrent overflow of reservoirs.
\end{abstract}

\section{Keywords}

Flood, Overflow, Warouwaye Lake, Simulation, Epaswmm

\section{Introduction}

The vulnerability of the Dakar region to flooding stems from natural, socioeconomic and political determinants. Indeed, the landscape of the region is marked 
by alternating dunes and inter-dune depressions called Niayes [1], it only takes a few hours of rain to see streets, houses and some public buildings under water. These recurrent winter flooding disasters in recent years in the Dakar region are due to a combination of natural and anthropogenic factors: 1) the re-watering of lowlands dried up by years of drought; 2) the occupation of lowlands by spontaneous habitat; 3 ) the return to normal rainfall characterized by heavy rainfalls; 4) the rise in the water table; 5) the nature of the soils and the lack of planning of urbanization and sanitation infrastructures [2]. Thus, the climatic disturbance is not the only cause of these floods.

The return of rainfall in the early 2000s allowed the water table to rise. Under these conditions, even low rainfall could lead to flooding of the lowlands and homes. These floods are not the result of exceptional rainfall events on an annual scale, although the intensity of rainfall on an hourly basis has increased [3] cited by [4]. This rainfall recovery highlights the deficiencies in urban planning.

Yeumbeul Nord (YN), our study area, is not exempt from this litany of consequences of these disasters and lives, like some localities in the suburbs of Dakar, on the flow of rainwater that hinders the daily life of its inhabitants, especially during the winter months. Due to a morphology favorable to water stagnation, runoff is directed towards lakes, low-lying points. Lake Warouwaye is one of them. The latter is subject to overflowing because of its low capacity. These overflows can be accentuated with the fall of exceptional rain. The objective of this article is to evaluate the risks of overflowing rainwater from Lake Warouwaye in the case of a ten-year rainfall.

\section{Geographic Location}

\subsection{Presentation of the Study Area (North Yeumbeul)}

The study area covers a surface of $9 \mathrm{~km}^{2}$ [5]. According to the Senegalese National Agency for Statistics and Demography (ANSD) population projections report, the total population of Yeumbeul Nord (YN) was 200,318 in 2019 [6]. It represents one of the most populous arrondissement communes in Senegal. YN is located in the suburbs of Dakar in the department of Pikine more precisely in the Niayes arrondissement between $17^{\circ} 20^{\prime}-17^{\circ} 22^{\prime}$ west longitude and $14^{\circ} 46^{\prime}$ $14^{\circ} 48^{\prime}$ north longitude (Figure 1). The "Niayes" are dune depressions in which the water table of the Quaternary sands outcrops or sub crops. Figure 1 illustrates the location of the study area.

\subsection{Location of Warouwaye Lake}

Located in the Niayes depression zone, the YN lake system is formed by three closed depressions (Thiouroure, Warouwaye and Wouye) and regenerates. Urban sprawl occurs on an area with a hydromorphic profile [7].

Lake Warouwaye is located in the inter-dune depressions and receives runoff from several sub-watersheds. The characteristics of the lake are shown in Table 1. 


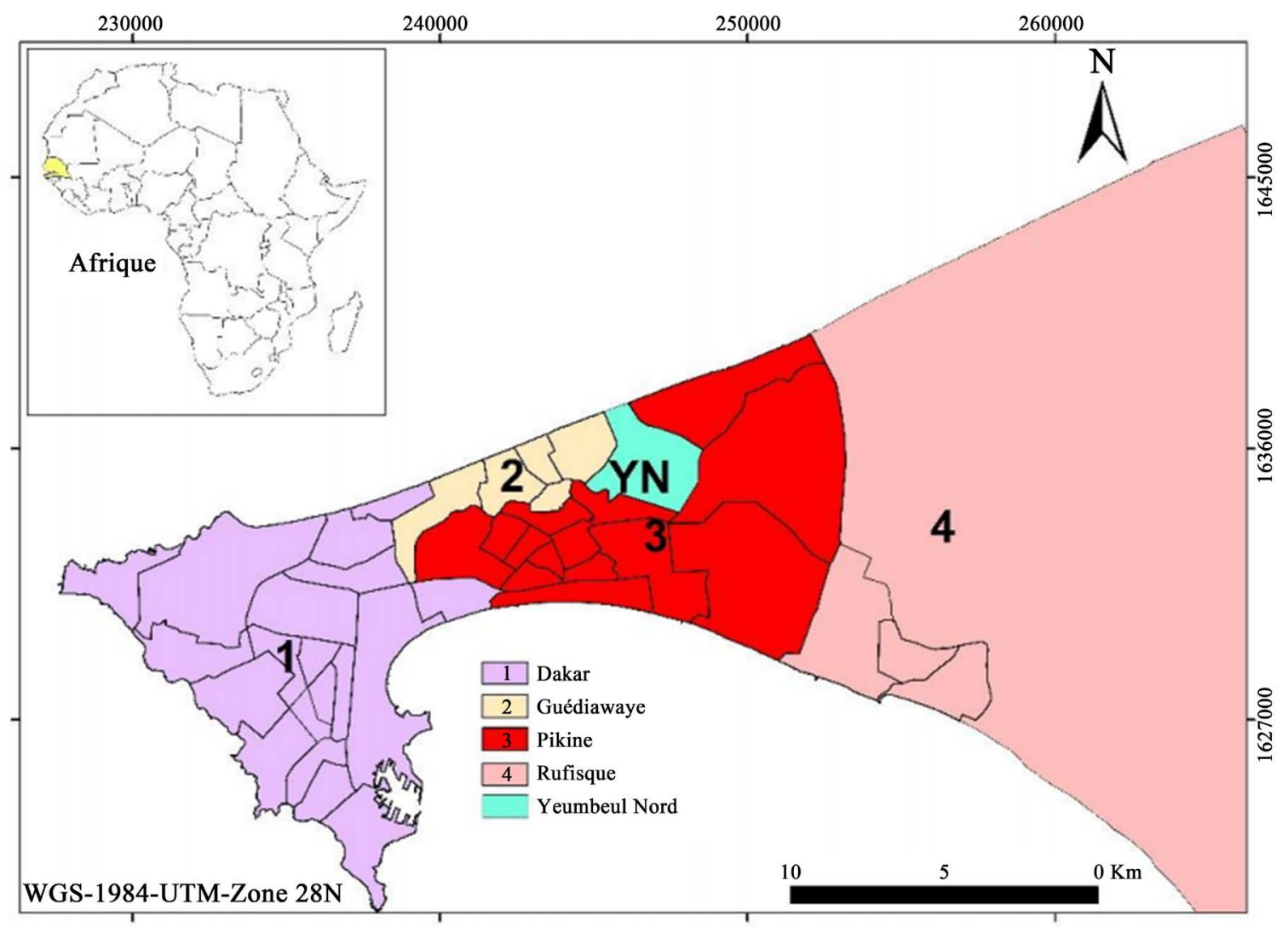

Figure 1. Location of the study area, YN [6].

Table 1. Characteristics of Lake Warouwaye [8].

\begin{tabular}{cccc}
\hline Area (ha) & Maximum depth $(\mathrm{m})$ & Lake storage capacity $\left(\mathrm{m}^{3}\right)$ & Total volume of the lake $\left(\mathrm{m}^{3}\right)$ \\
\hline 24.56 & 1 & 122425 & 245600 \\
\hline
\end{tabular}

\subsection{Land Use Ocation of Warouwaye Lake}

With the expansion of urbanization (Figure 2), this lake is experiencing filling problems threatening its hydrological and ecological functions. A large part of this reserve has become fragile and exposed to various environmental problems.

The lake's water level has decreased from about 54 to 25 ha between 2013 and 2020. It is increasingly overgrown with aquatic vegetation and causes nuisance to the riparian populations (garbage dumps and wildlife shelters). Even for bathymetric study purposes, this lake is difficult to access [9].

\subsection{Degradation of the Living Environment}

$\mathrm{YN}$ is one of the last wetlands in the Dakar region where natural areas are rare. In the context of a significant decrease in rainfall during the 1970 [1], the decrease in the water table has led to a drying up of the Niayes. However, a progressive reduction in the surface area of the lake was noted, mainly due to the expansion of the built-up area. The vegetation that used to predominate in the area has been greatly degraded. 


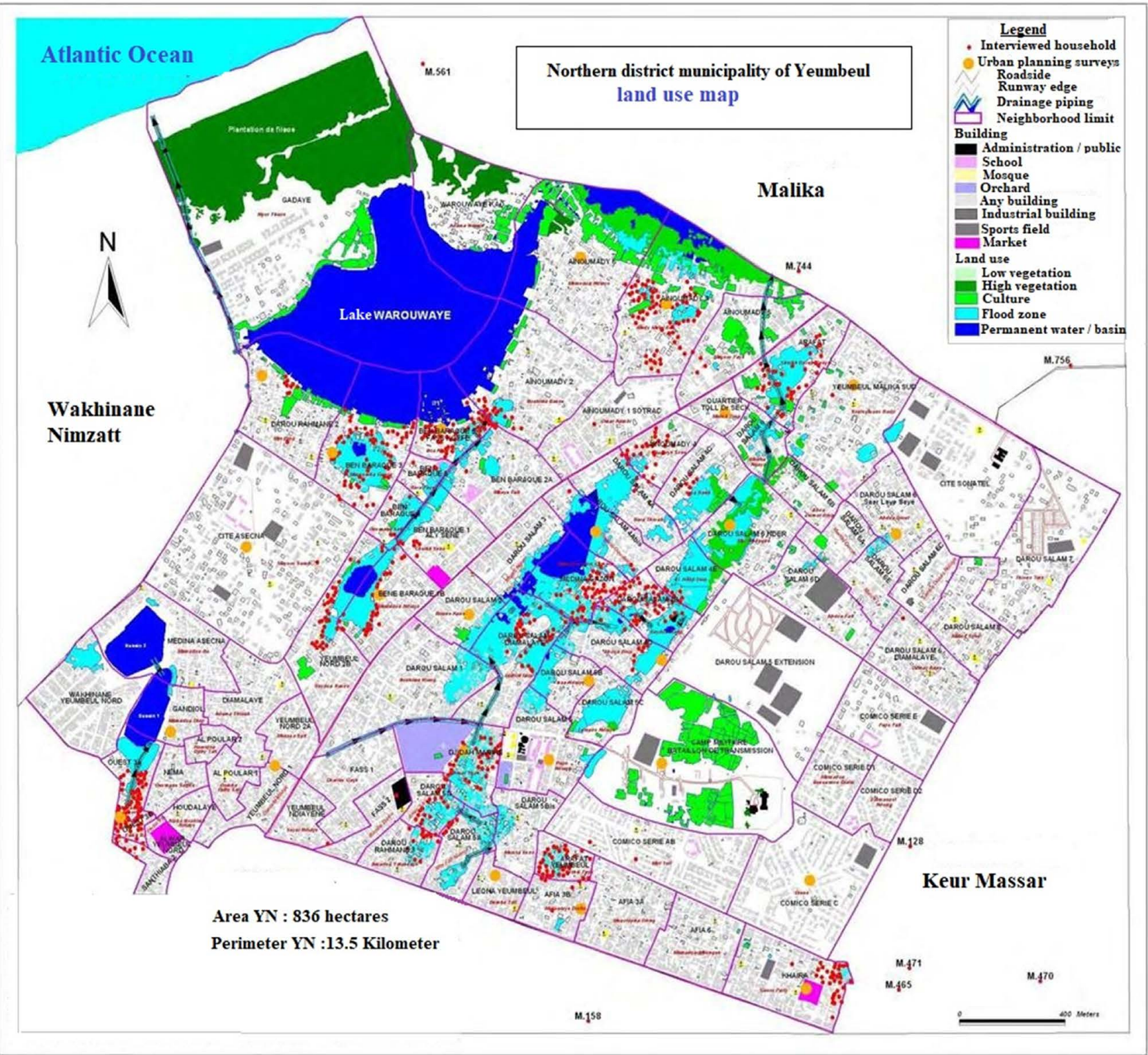

Figure 2. Land use map of YN [9].

Currently, the built-up area is expanding into the wetland depressions as almost all of the available space around the lakes is occupied. The densification of the road network leads to a fragmentation of the ecosystem. The extension of the road network, for example, encourages the occupation of low-lying areas without prior development. As a result, urbanization has strongly amplified the consequences of the great drought on wetlands [1]. The development of buildings and road infrastructure is the main factor in the disappearance of wetlands and the modification of their hydrological system.

Another environmental risk is that the wetlands have long been considered unhealthy and unproductive. The majority of the population considers the Niayes to be cumbersome, mainly due to the presence of mosquitoes, and uses it as a garbage dump. Household waste and rubble usually deposited along the lake- 
shore can be washed in by runoff.

All these anthropogenic factors threaten the preservation of these ecosystems, already weakened by the advancing urban front. Photo 1 and Photo 2 illustrate the degradation of this area with a poorly developed outlet and abandoned houses in the low-pressure areas.

\section{Materials and Methods}

A bibliographic search allowed us to review the issue of flooding in Dakar and to define the physical and human framework. The reports, theses and articles on the subject of floods have especially allowed us to know the state of research and the problematic posed.

For the implementation of this work, the first phase consisted in gathering and analyzing the necessary basic data that are available. The data collection part was done with the different data managers and concessionaires of the drainage and development network such as the National Agency of Civil Aviation and

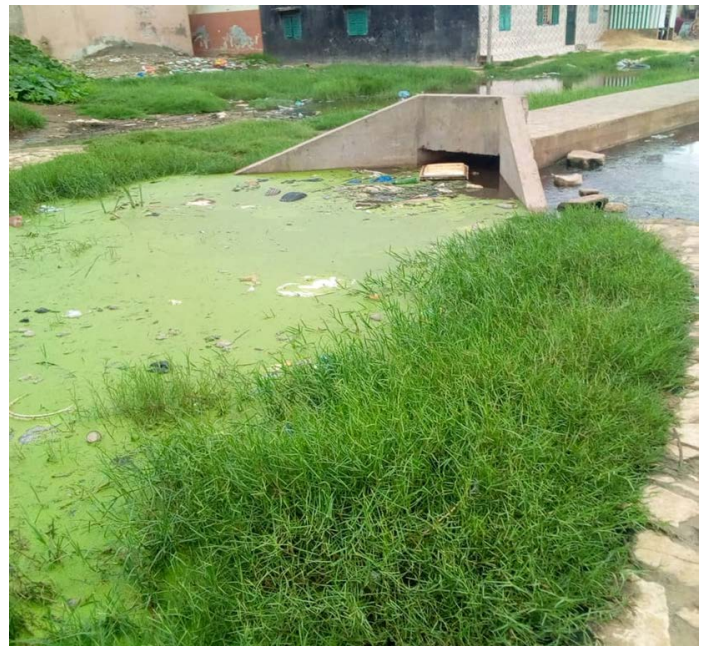

Photo 1. Degradation of vegetation cover.

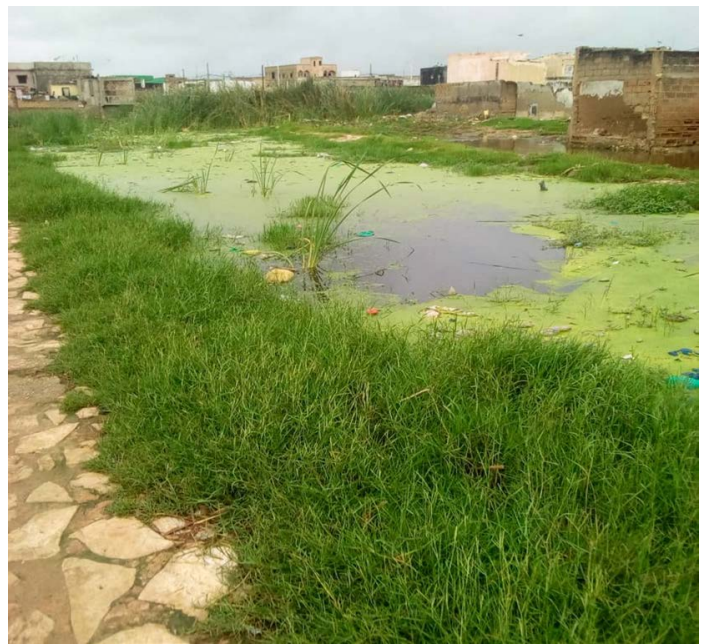

Photo 2. Occupation of low areas. 
Meteorology (ANACIM), the National Office of Sanitation of Senegal (ONAS), the Municipal Development Agency (ADM).

Processing is facilitated by software such as Google Earth, Global Mapper, Excel and Epaswmm.

Google Earth software allowed us to locate the geographical area of YN and the recognition of the terrain, Global Mapper for the delimitation of watersheds and the generation of contours, Epaswmm to make hydrological and hydraulic simulations of the network.

The existing drainage plan for Yeumbeul and the data for Lake Warouwaye (capacity, maximum lake depth, and surface area) (Table 1) was very useful in conducting the comparative study of the network.

The analysis of rainfall events in our sample will allow us to determine these different characteristics and to propose a Desbordes-type and Kieffer-type project rainfall model with a 10-year return probability.

\subsection{Rainfall Data}

A 30-year series (1990-2019) of annual rainfall (Figure 3) was used as rainfall data. This series is likely to give a representative mean value for the Dakar/Yoff station.

Flooding in YN often occurs during the rainy season, beginning in July and ending in October with a peak during August [10].

\subsection{Intensity-Duration Frequency}

The rainfall data for the area are obtained after exploitation of the Master Drainage Plan (MDP) [11] in which the authors used the work of Brunet-Moret (1963) for the current ORSTOM IRD. These studies are based on the analysis of rainfall records and rain gauge recordings and aim to establish Intensity-Duration-Frequency (IDF) curves for various recurrence periods over the entire Senegalese territory. In order to exploit the Intensity-Duration graphs of the

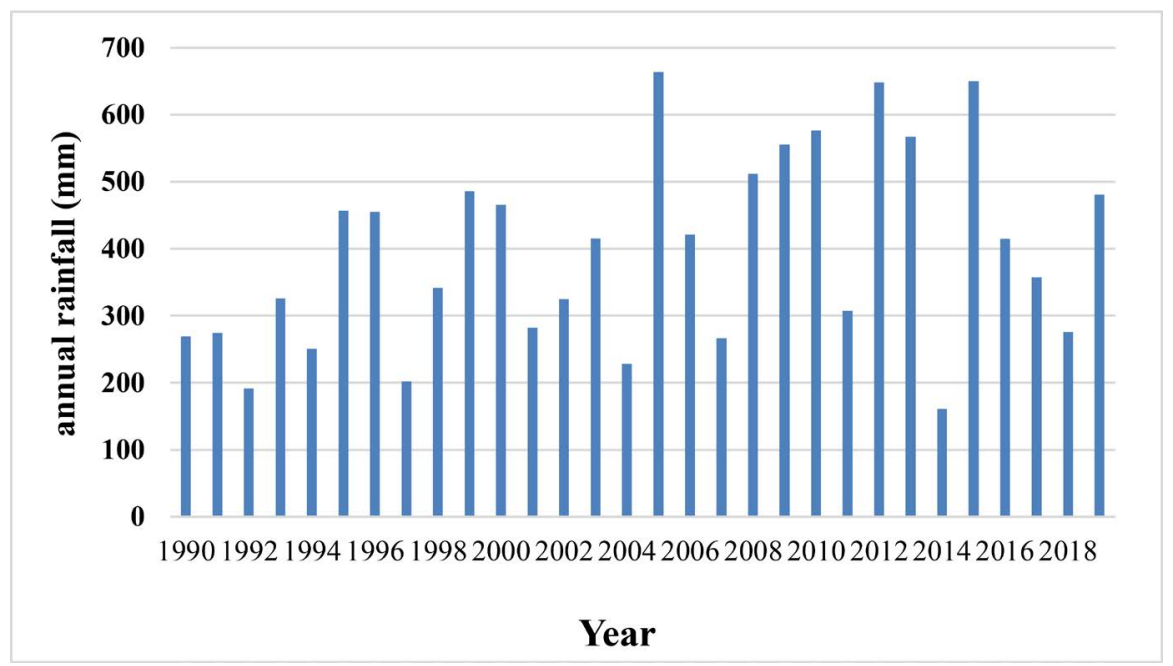

Figure 3. Annual rainfall series (1999-2019). 
Brunet-Moret study, the MDP recalculated the daily rainfall of the Dakar region for different return periods (Table 2).

\subsection{Rain Intensity: Montana Formula}

Several equations can be used to describe adaptive IDF curves, capable of taking into account climate trends. In the sub-region and in Senegal, the Montana formula remains the most widely used. It describes the relationship between the intensity, duration and frequency of rainfall. It is expressed as follows (Equation (1)).

$$
I=a t^{-b}
$$

With, $I$ : average intensity in $\mathrm{mm} / \mathrm{h} ; t$. rain duration in min; $a$ and $b$ : adjustment coefficients of Montana's law defined for a return period $T$ (years).

Figure 4 below shows that the decadal IDF curve shows a break and thus allows us to determine the values of Montana coefficients.

In the calculations, the formula defined previously (Equation (1)) gives two expressions of the intensity of the showers. Indeed, the graph allows to see the accuracy of the evolution of the intensity as a function of time.

$$
\text { Pour } T=10 \text { years } \begin{cases}I=9.0038 t^{-0.522} & \text { for } t<1 \mathrm{~h} \\ I=42.232 t^{-0.846} & \text { for } t>1 \mathrm{~h}\end{cases}
$$

- The concentration time by the Desbordes method is expressed by Equation (3).

$$
T c=\frac{5.3}{0.8} \cdot S^{0.3} \cdot P^{-0.38} \cdot C^{-0.45}
$$

With:

Tc. concentration time in min; $S$ : surface in Ha; $P$. Slope in \% and $C$ : Runoff

Table 2. Intensity-Duration-Frequency (IDF) in the Dakar region [11].

\begin{tabular}{cccccccccc}
\hline & \multicolumn{10}{c}{$T=10$ YEARS } \\
\hline$t(\mathrm{mn})$ & 15 & 30 & 60 & 120 & 240 & 360 & 480 & 720 & 1440 \\
$i(\mathrm{~mm} / \mathrm{h})$ & 130 & 93.5 & 65 & 44 & 25.5 & 17.19 & 13.9 & 9.7 & 5.4 \\
$i(\mathrm{~mm} / \mathrm{min})$ & 2.16 & 1.55 & 1.08 & 0.73 & 0.42 & 0.28 & 0.23 & 0.16 & 0.09 \\
\hline
\end{tabular}

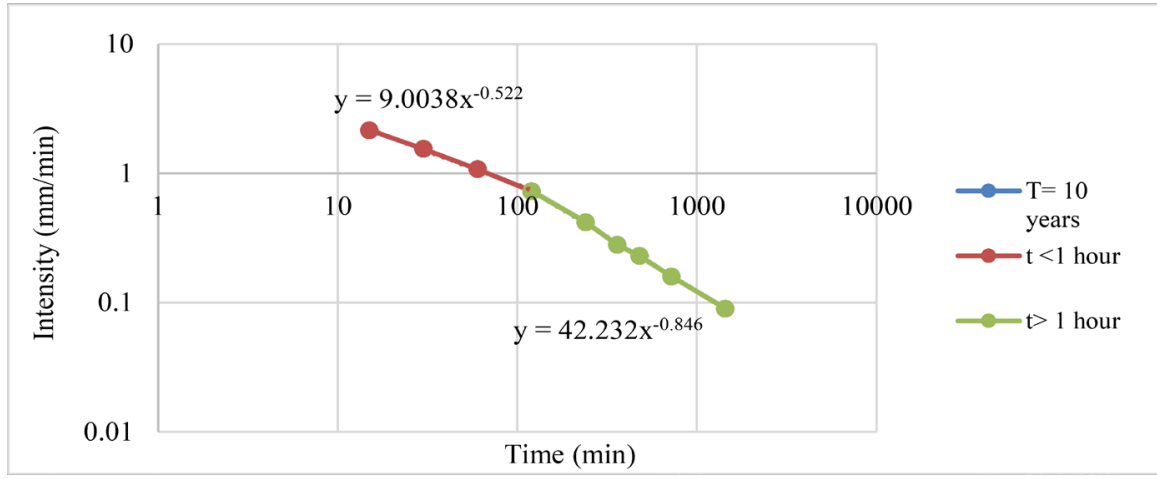

Figure 4. Reference intensity-duration-frequency curve for $T=10$. 
coefficient.

- The runoff coefficient of a given surface is the ratio of the volume of water that runoff to the volume of water falling on it. In the context of our study area, which is urbanized, the coefficient is defined as the ratio of the impervious surface to the total surface of the watershed (land use) and the type of soil (Table 3).

For the site, we note a diversity of occupation mode and soil type.

\subsection{Method of Estimating Flow Rates and Runoff Volumes Using the Rational Method}

For the choice of the method of calculation of the flows, we studied the validity of the various existing methods of estimation compared to the characteristics of the zone and the catchment areas obtained. The rational method is used to estimate the flows to be drained to the retention basins that are the Warouwaye and Thiouroure lakes. This method uses a model of transformation of rain, described by its intensity considered as uniform in time, into a maximum instantaneous flow at the outlet. The rational method allows the calculation of each sizing flow of the drainage network starting at the head of the basin. This flow is given by Equation (4):

$$
Q=0.278 \times C \times I \times A
$$

With, $Q$ : Maximum flow at the outlet expressed in $\mathrm{m}^{3} / \mathrm{s} ; C$ : Runoff coefficient; I: Rainfall intensity expressed in $\mathrm{mm} / \mathrm{h} ; A$ : Watershed area in $\mathrm{Km}^{2}$.

Despite its limitations, the rational method provides good results.

The runoff coefficient used is that of the drained areas. It corresponds to the ratio of the impervious surface to the total surface of the watershed.

Table 3. Runoff coefficients by soil family and land use type [12].

\begin{tabular}{cc}
\hline Type of land use & Runoff coefficients \\
\hline Individual housing of the villa type & 0.49 \\
Planned housing company type & 0.60 \\
Irregular spontaneous habitat & 0.64 \\
Regular spontaneous habitat & 0.57 \\
Housing type building & 0.80 \\
Village type habitat & 0.63 \\
Artisanal zone & 0.57 \\
Industrial zone & 0.54 \\
Equipment-heavy waterproofing & 0.64 \\
Equipment-medium waterproofing & 0.50 \\
Equipment-low waterproofing & 0.40 \\
Green spaces & 0.13 \\
Water plan & 0.95 \\
\hline
\end{tabular}




\subsection{Simulation with Epaswmm Software}

The Epaswmm software was used for the simulations that allow to appreciate the hydrological behavior of the Warouwaye Lake according to different rainfalls of 10 years return period in order to appreciate the contributions of water at risk of flooding following the overflow of the lake.

\section{- Project rain}

Five (5) project rains was used for the simulations, including four short rains of intense duration ( $15 \mathrm{~min}, 30 \mathrm{~min}, 60 \mathrm{~min}$ and $120 \mathrm{~min}$ ) over a period of 4 hours and one long Kieffer-type rain of 24 hours duration.

The project rainfall is summarized in Table 4 below.

\section{- Kinematic wave runoff model}

It is a conceptual model that represents the watershed as a rectangular channel with a free surface.

The inflow $Q_{e}(t)$ corresponds to the excess precipitation (precipitation-infiltration-evaporation-interception by vegetation or depressions on the surface of the BV) (Figure 5).

The outflow $Q_{s}(t)$ is calculated at each time step using the Manning-Strickler formula from the characteristics of the channel (width and roughness) and the height $h(t)$ of the water flowing in the channel [14].

$$
\begin{gathered}
Q_{s}(t)=S H(t) \cdot R H(t)^{2 / 3} \cdot \sqrt{p} \\
S H(t)=B \cdot h(t) \\
R H(t)=\frac{B \cdot h(t)}{B+2 h(t)}
\end{gathered}
$$

With, $S H$ : represents the surface area of the watershed; $R H$ : is the hydraulic

Table 4. Projected rainfall for a 10-year return period [13].

\begin{tabular}{cccccc}
\hline Rain duration & $4 \mathrm{~h}-15 \mathrm{~min}$ & $4 \mathrm{~h}-30 \mathrm{~min}$ & $4 \mathrm{~h}-60 \mathrm{~min}$ & $4 \mathrm{~h}-120 \mathrm{~min}$ & 24-type Kieffer \\
\hline $\mathrm{H}(\mathrm{mm})$ & 101.94 & 102.03 & 102.0 & 102.0 & 129.8 \\
\hline
\end{tabular}

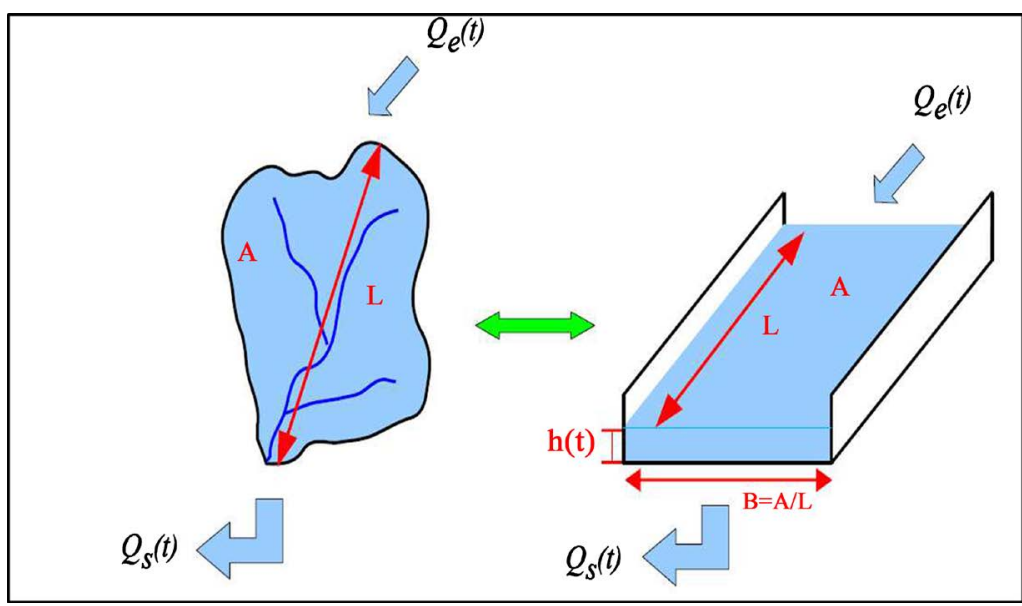

Figure 5. Schematic of the EPA SWMM runoff model. 
radius; $h(t)$ : is the height of the water runoff; $p$ : is the slope of the watershed.

\section{Results}

\subsection{Topography of the Area}

Examination of the digital terrain model (DTM) highlights the elevations of the area, the hydrographic network and the drained watersheds. The contour lines and the variation in the coastline of the resulting area are shown in Figure 6.

Elevations are low in the $\mathrm{YN}$ area, but are lower at the lakes. This suggests that the lakes are a natural depression or outlet for runoff. Lake Warouwaye is $0 \mathrm{~m}$ high (source: Google Earth).

\subsection{Watersheds Delineated by Global Mapper}

After generating the direction of water flow, we were able to obtain different sub-watersheds represented in Figure 7.

\subsection{Watershed Characteristics}

Following the delimitation of the watersheds, we were able to observe the flow of two main rivers that drain the waters of $\mathrm{YN}$, but also those of Djidah Thiaroye Kao, Medina Gounass, the northern part of South Yeumbeul, Wakhinane Nimzatt, and which have as their outlet the lakes Warouwaye and Wouye. In this study, we will focus on the catchment areas that have Lake Warouwaye as their outlet in order to study the risk of overflow from the latter, which is located within North Yeumbeul. The Warouwaye (BVW) and Thiouroure (BVT) watersheds cover an area of 1124 ha and their characteristics are presented in Table 5.

All of the watersheds in this area are considered small watersheds because they are less than $10 \mathrm{~km}^{2}$ in size. Thus, the Gravelius compactness index of each

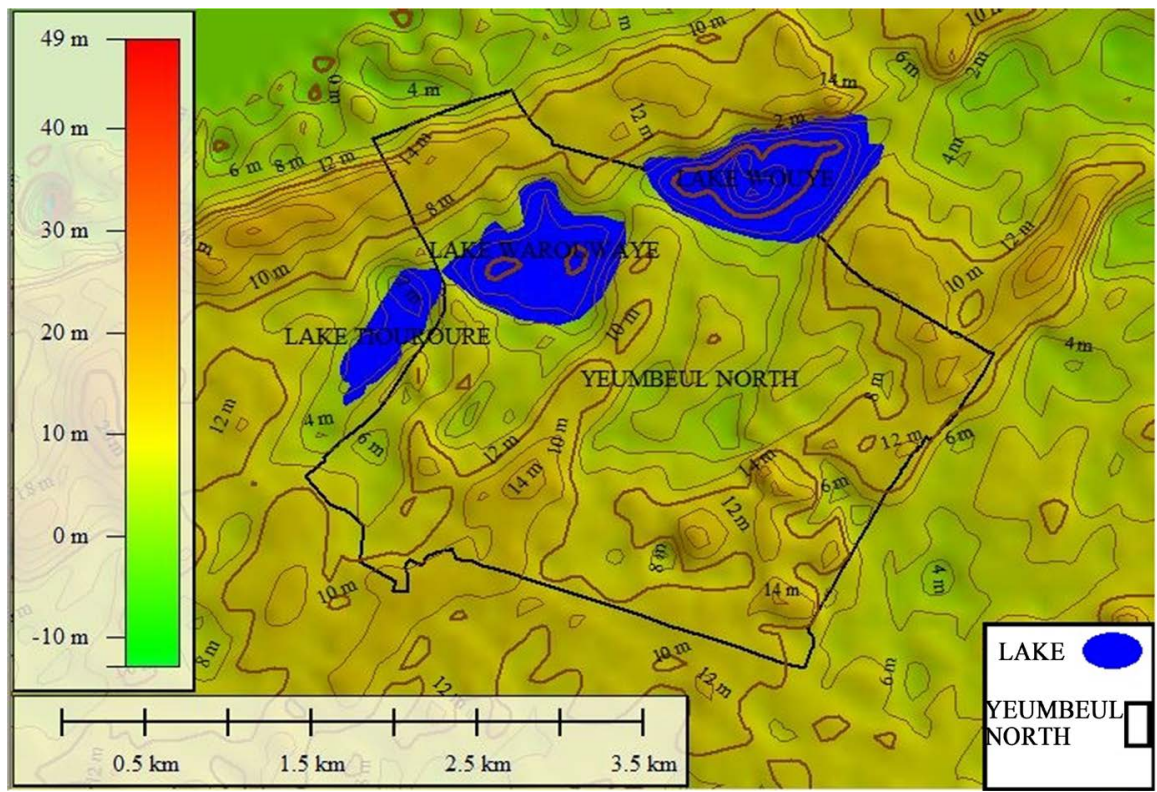

Figure 6. Topography and contour lines. 
of these watersheds is 2.08 for BVW (very long watershed) and 1.6 for BVT (watershed 6 times longer than wide).

\subsection{Estimation of Project Flows}

The discharge at the outlet of the two watersheds estimated by the rational method is given in Table 6 .

\subsection{Simulation Results on Epaswmm}

The normal water surface of the lake is 24.56 hectares with a maximum depth of $1 \mathrm{~m}$. The total volume of the normal water body of Lake Warouwaye is 245,600 $\mathrm{m}^{3}$, but due to dysfunctions caused by natural causes such as wind deposits, the invasion of aquatic plants, and also to numerous causes of anthropogenic origin, the lake can only retain $122,425 \mathrm{~m}^{3}$ of the total runoff volume.

In the following, we will present and comment on the simulation results of

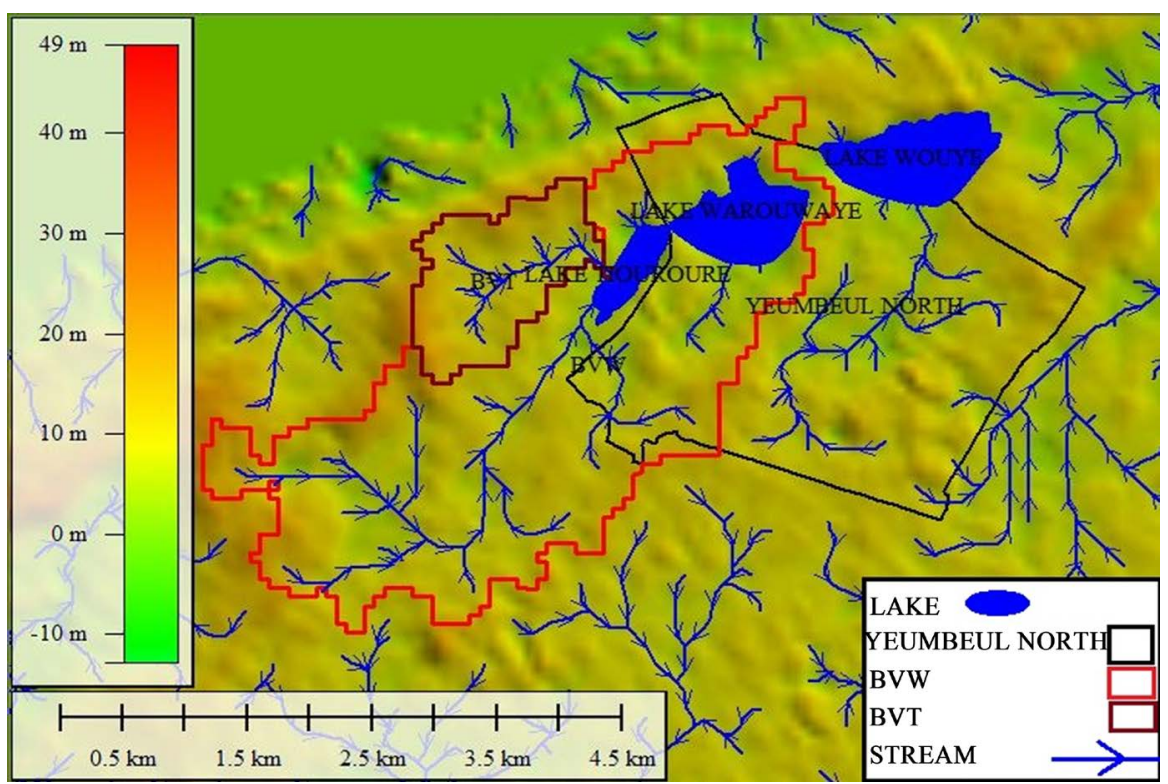

Figure 7. Watersheds of Yeumbeul.

Table 5. Characteristics of the Warouwaye ponds.

\begin{tabular}{ccccccc}
\hline BV & Area $\left(\mathrm{km}^{2}\right)$ & Area (ha) & $\begin{array}{c}\text { Perimeter } \\
(\mathrm{km})\end{array}$ & $\begin{array}{c}\text { Max altitude } \\
(\mathrm{m})\end{array}$ & $\begin{array}{c}\text { Min altitude } \\
(\mathrm{m})\end{array}$ & $\begin{array}{c}\text { Average } \\
\text { slope (\%) }\end{array}$ \\
\hline BVW & 9.664 & 966.40 & 23.05 & 23 & -1 & 1.66 \\
BV T & 1.577 & 157.70 & 7.18 & 23 & 6 & 1.67 \\
\hline
\end{tabular}

Table 6. Estimates using the rational method.

\begin{tabular}{ccccccc}
\hline Watershed & Area $\left(\mathrm{km}^{2}\right)$ & $C(\%)$ & Slope (\%) & $\begin{array}{c}T c(\mathrm{~min}) \text { DESBORDES } \\
\text { method }\end{array}$ & $I(\mathrm{~mm} / \mathrm{h})$ & $Q\left(\mathrm{~m}^{3} / \mathrm{s}\right)$ \\
\hline BVW & 9.66 & 0.75 & 1.66 & 48.90 & 68.12 & 137.26 \\
BVT & 1.58 & 0.75 & 1.67 & 28.32 & 42.30 & 13.91 \\
\hline
\end{tabular}


four (4) Desbordes-type and one (1) Kiefer-type project rainfall events.

- Intense short duration DESBORDES type rainfall

The actual rainfall events causing disruptions in storm water systems generally consist of a relatively short period of intense rainfall within a rain sequence of a few hours. Desbordes therefore proposed to choose a particular form of project rainfall by reasoning not in relation to the physical phenomenon, but in relation to the elements to which the runoff model (used after the rainfall model) was the most sensitive. This sensitivity analysis, conducted from the linear reservoir model, showed that a simple double triangular shape provided hydrograph shapes and maximum flow values that were not very sensitive to errors on the main parameter of the runoff model.

The passage of each of these rains caused overflows (red curve) at the level of the lake with variable volumes of water largely higher than the capacity of the lake.

Figures 8-11 represent the curves of volumes entering the lake versus time and maximum storage capacity $\left(122,425 \mathrm{~m}^{3}\right)$.

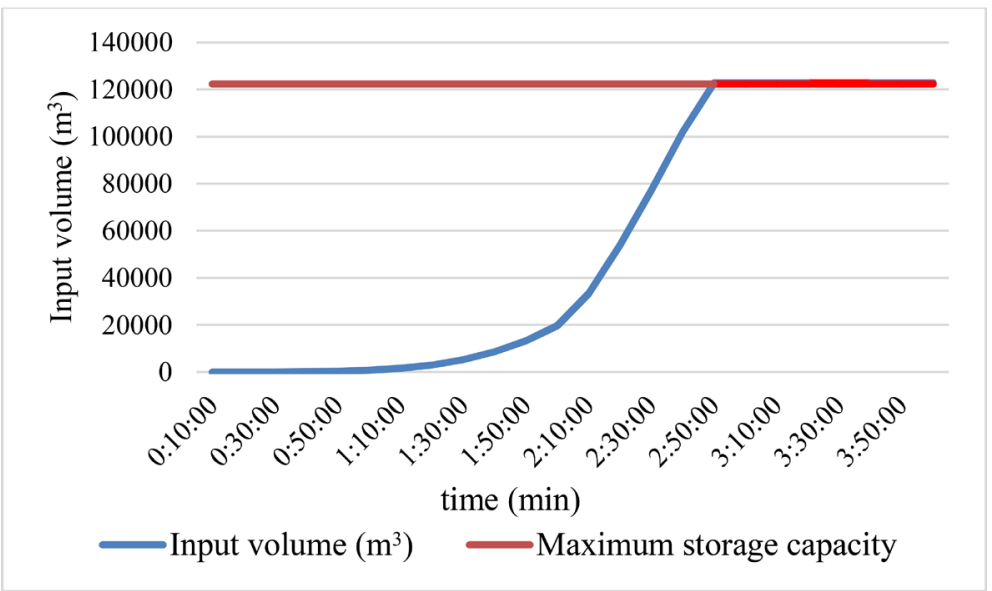

Figure 8. Variation of incoming volume for a $4 \mathrm{~h}-15 \mathrm{~min}$ DESBORDES type rain.

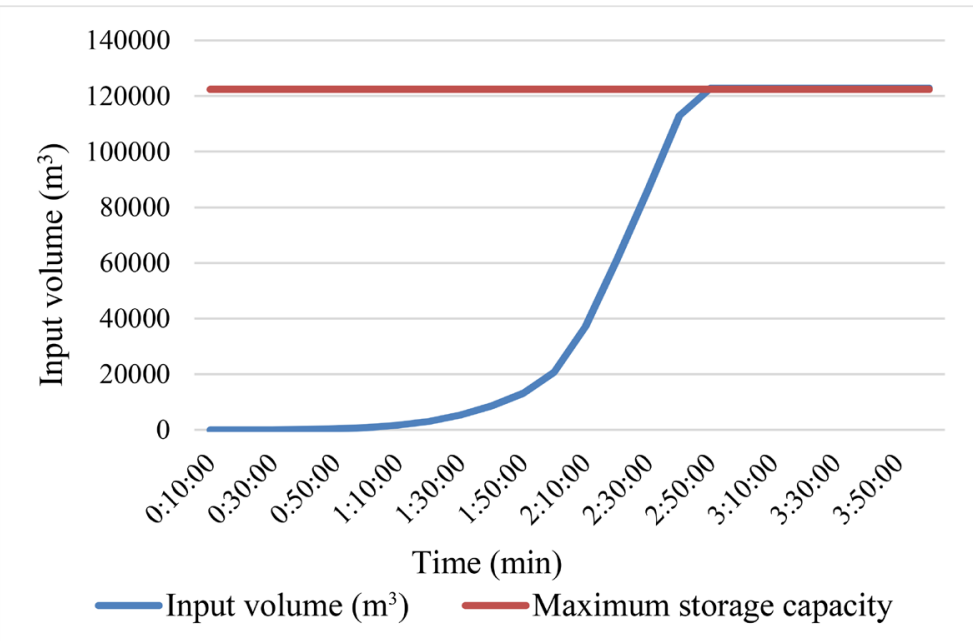

Figure 9. Variation of incoming volume for a $4 \mathrm{~h}-30 \mathrm{~min}$ DESBORDES type rain. 


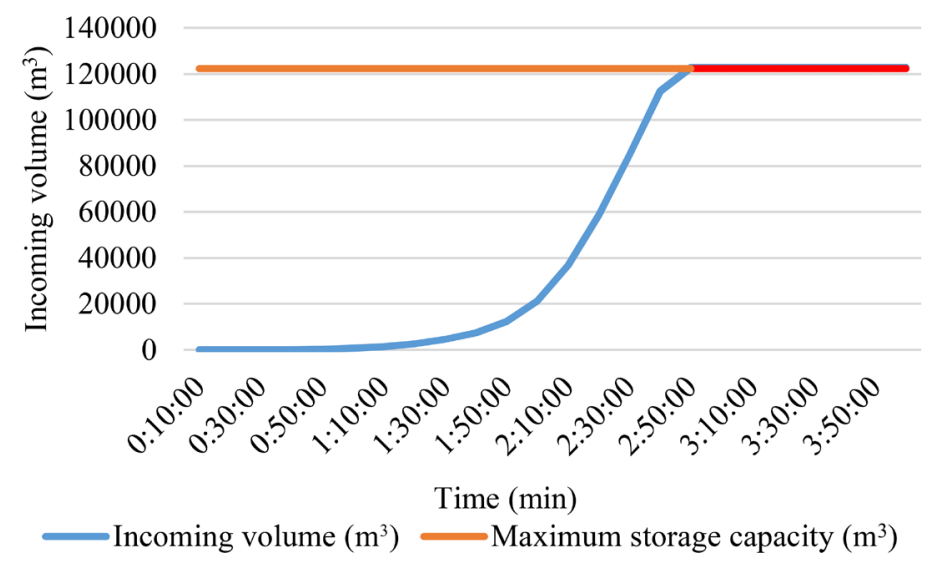

Figure 10. Variation of incoming volume for a $4 \mathrm{~h}-60 \mathrm{~min}$ DESBORDES type rain.

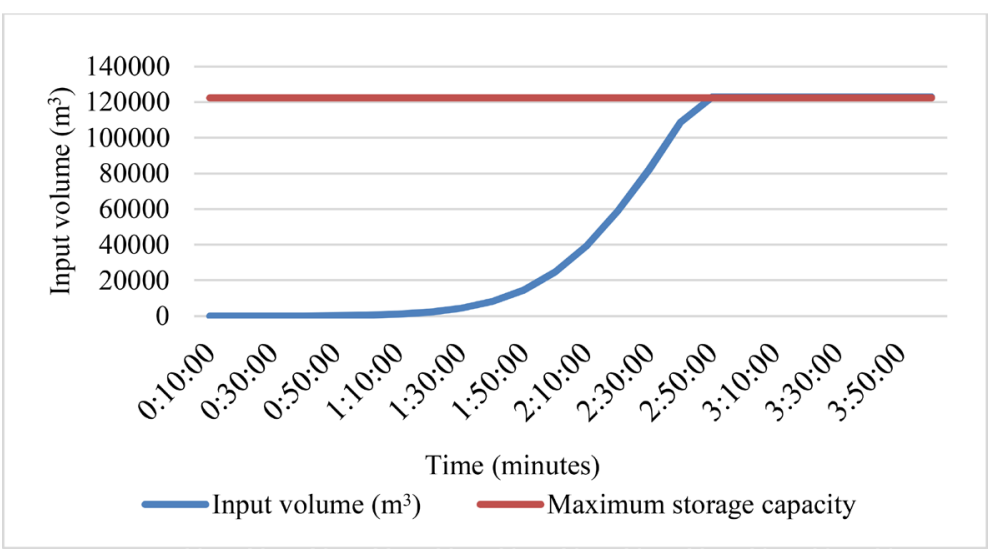

Figure 11. Variation in inflow volume for a $4 \mathrm{~h}-120$ min DESBORDES type rainfall.

For all these different rainfall events of the Desbordes 4-hour type with intense durations of $15,30,60,120$ minutes, the quantity of water received by the lake is always greater than the maximum storage capacity $\left(122,425 \mathrm{~m}^{3}\right)$.

- For a 24-hour KEIFER-type rainfall of long duration

This project rainfall was proposed by Keifer and Chu (1957). It consists in transforming directly the IDF curves (represented by the classical Montana formula) into hyetograms. This method leads to an excessive overestimation of the peak flows generating a flood wave in the hydrological system (runoff-network) never observed in situ.

The passage of this rain caused the greatest overflow of the lake with a volume of $1,063,020 \mathrm{~m}^{3}$ greater than the storage capacity $\left(122,425 \mathrm{~m}^{3}\right)$, i.e. an overflow of $939,330 \mathrm{~m}^{3}$. Figure 12 gives us the variation curve of the volume entering the lake compared to the maximum capacity.

Table 7 presented below permit us to summarize the results of the system-wide simulations.

Therefore, Lake Warouwaye has a transit limit of a certain occurrence that is tested by the simulated passage of different types of project rainfall, causing overflow of runoff water to the nearby residential areas. 


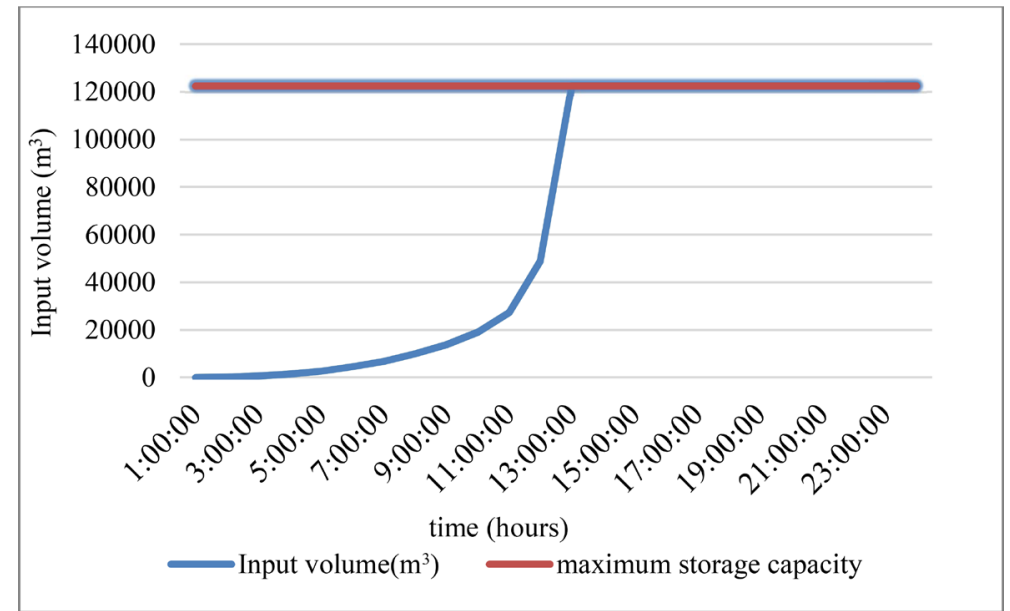

Figure 12. Variation in inflow volume for a 24-hour Kiefer-type rainfall.

Table 7. Summary of the results of the Lake Warouwaye overflow study.

\begin{tabular}{ccccccc}
\hline Type of rain & $\begin{array}{c}\text { BV area } \\
\text { (ha) }\end{array}$ & $\begin{array}{c}\text { Run-off } \\
\text { water } \\
(\mathrm{mm})\end{array}$ & $\begin{array}{c}\text { Volume of } \\
\text { water runoff } \\
\left(\mathrm{m}^{3}\right)\end{array}$ & $\begin{array}{c}\text { Runoff } \\
\left(\mathrm{m}^{3} / \mathrm{s}\right)\end{array}$ & $\begin{array}{c}\text { Runoff } \\
\text { coefficient } \\
(\%)\end{array}$ & $\begin{array}{c}\text { Maximum } \\
\text { lake storage } \\
\text { capacity }\left(\mathrm{m}^{3}\right)\end{array}$ \\
\hline 4 h - 15 mn type DESBORDES & 1124.1 & 88.355 & 953,880 & 47 & 86.5 & \\
$4 \mathrm{~h}-30$ mn type DESBORDES & 1124.1 & 88.465 & 955,320 & 47.16 & 86.5 & \\
$4 \mathrm{~h}-60$ mn type DESBORDES & 1124.1 & 88.44 & 955,070 & 48.15 & 86.5 & 122425 \\
4 h - 120 mn type DESBORDES & 1124.1 & 88.435 & 955,020 & 48.83 & 86.5 & \\
KEIFER type rain & 1124.1 & 101.935 & $1,063,020$ & 61.12 & 78.8 & \\
\hline
\end{tabular}

One of the consequences of this hydrological dysfunction is the recurrence of floods, in the face of which the Senegalese government has displayed a firm political will to definitively curb this phenomenon.

\section{Conclusions}

At the end of this study, by making a diagnosis on the lake, it appears that its capacity is very insufficient and is strongly disturbed. The main objective of this study being to study the overflows during the wintering, we used the various project rainfalls for a return period of 10 years defined in the Drainage Master Plan of (DMP) as input data at the level of the EPASWMM software.

After simulation, it is observed that the passage of these various rain events all cause overflows of the basin and that the volumes entering the lake are largely higher than the storage capacity of the basin.

For a better functioning of Lake Warouwaye and consequently better management of floods by the overflow of this one, we recommend to:

Ensure periodic rehabilitation of the lake by dredging to increase its capacity;

Proceed with the removal of aquatic vegetation;

Evacuate the overflow of water to the sea when the critical level is reached by continuous pumping. 
Update of the drainage and collection master plan for the neighborhoods located in the depression zones such as YN, Djiddah Thiaroye Kao, North-East of Thiaroye and the western part of YN.

\section{Conflicts of Interest}

The authors declare no conflicts of interest regarding the publication of this paper.

\section{References}

[1] Diop, A., Diop, C., Ntiranyibagira, E., Dacosta, H., Sambou, S. and Sambou, H. (2018) Land Use Dynamics of Urbanized Wetlands in Dakar (Senegal) from 1942 to 2014.

[2] Wade, S.A.L. (2008) Remote Sensing and Natural Disaster Management: Applications to the Study of Urban Flooding in Saint-Louis and Gullying Related to Water Erosion in Nioro6 Du-Rip (Senegal). Editions des Archives Contemporaines, 8, 203-210.

[3] Dacosta, S. (2009) Flooding in Dakar and the Sahel: Sustainable Rainwater Management. Dakar, Enda Editions, 265.

[4] ADEPT (2010) Floods in Dakar and Suburbs: Better Understanding the Causes for Sustainable Solutions. Proceedings of the Colloquium, CESAG in Dakar, 11-12 June 2010,65

[5] Sy, B. (2019) Multidisciplinary Approach to Flood Hazard Assessment in Yeumbeul Nord, Dakar, Senegal: The Contribution of Citizen Science. PhD Thesis, University of Geneva.

[6] National Agency of Statistics and Demography (ANSD) (2019) Projection of the Senegalese Population to 2035.

[7] Diongue, M. (2014) Urban Periphery and Flood Risks in Dakar (Senegal): The Case of Yeumbeul Nord. ESO Travaux et Documents, 37, 54.

[8] ADM (2011) Storm Water Management and Climate Change Adaptation Project: Report of the Municipal Development Agency, 142.

[9] IAGU (2013) Flooding in the Suburbs of Dakar: Towards Adaptation through Improvements in Buildings, Infrastructure and Local Governance to Reduce the Vulnerability of Household and Community Assets. Final Technical Report, 57.

[10] National Agency of Civil Aviation and Meteorology (ANACIM) (2020) Rainfall Records from the Dakar-Yoff Rainfall Station.

[11] EDE (2012) Study of the Drainage Master Plan (DMP) for Storm Water in the PeriUrban Region of Dakar, Final Study Report, Municipal Development Agency (ADM), Dakar, 320.

[12] Ndao, S. (2017) Contribution to the Rainwater Sanitation of the Dakar Region: Study of Recurrent Flooding in the Niayes Area (Case of the Localities of Grand Yoff and Thiaroye). University of Thiès, Thiès, 188.

[13] Groupement SGI/Cabinet Merlin/EDE (2012) Drainage Master Plan (DMP) Study of Storm Water in the Peri-Urban Region of Dakar, Final Study Report, Municipal Development Agency (MDA), Dakar, 320.

[14] Telliez, M. (2010) Initiation Manual EPA SWMM 5, 28. 